\title{
Seeding green roofs with native grasses
}

\author{
Richard K. Sutton ${ }^{1}$ \\ ${ }^{1}$ Professor, University of Nebraska-Lincoln, Lincoln, NE, rsutton1@unl.edu
}

Sutton, R., 2013. Seeding green roofs with native grasses. Journal of Living Architecture. 1(1): 15-35.

http://greenroofs.org/resources/JOLA2013Volume1(Issue1)Sutton 


\begin{abstract}
During six years of native grass establishment and growth on four green roofs, we sought to understand appropriate seeding seasons and spacing, the amount of time to reach the industry $80 \%$ coverage threshold (FLL 2008), the seed yield projections for volunteer plant infill. We also produced and tested methods for successfully and inexpensively seeding and determined "as needed" irrigation protocols. The suite of techniques examined improves and enhances the use, establishment, and management of native grasses on green roofs and reduces green roof costs.
\end{abstract}

Key Words: cost analysis, biodiversity, plant cover, grass seeding

\title{
Introduction
}

Planting rooftops (i.e., roof greening) continues to burgeon in North America (Narejo 2010, GRHC 2013), yet installation and establishment are still slow and expensive. Unfortunately green roofs remain oddities and to be more widely deployed they must become commodities. Below we describe how green roof planting can become simplified, less costly and more diversified.

While vegetated layers must adapt to extreme temperature, drought, and wind, as a sustainable green infrastructure, they must also quickly cover and stabilize the growing substrate. During and after establishment, plants must limit wind scour and self-heal gaps with creeping and rooting stems or by reseeding, Mono-generic, creeping species of Sedum, predominate on green roofs and are most often hand-plugged into substrate, placed via expensive, pre-grown trays and mats or in a few cases sown as live sprigs. Plugged sedum, depending on its initial size and spacing, may take two years to meet the $85 \%$ industry coverage standard (Snodgrass and McIntyre 2010). The FLL (2008) standard is $80 \%$ and three years' establishment time is common. Sprigs require intensive management to establish.

The green industry has dealt with the expense and speed of covering large, ground level landscapes by sodding with grasses, although it costs 19 times more to do so than seeding (Page 1999). Meanwhile, the specialized agricultural equipment for producing, shipping, and installing sod is not feasible for green roof use. A notable exception to this approach was the Ford's Rouge River Truck plant green roof project that happened to contain ample space for growing sedums on-site to be placed as mats.

Planting of North American native grasses and forbs on green roofs also continues to occur (Sutton et al 2012). A quick Google search using the key words, green roof and native plant, produced 67 citations with 7 covering native plants and just two (Beitz 2011, Sutton et al 2012) focusing exclusively on grasses or grassland communities. Others dealt with native grasses combined with Sedum spp. (e.g., Monterusso et al, 2005, Bousselot et al 2009, Bousselot et al 201). As a reflection of current green roofs, dozens of citations dealt with research only on Sedum.

Some native grasses such as blue grama, sideoats grama and little bluestem are widely used on green roofs befitting of their widespread natural habitats. Green roof projects like the LDS Conference Center in Salt Lake, Phillips Eco-Center in Minneapolis, Vancouver's Convention Centre, PECO Headquarters in Philadelphia, and the Chicago City Hall represent prominent examples of where 
native grasses moved from original plugs, self-seeded, and filled gaps. Given these facts, it is odd that completely seeded green roofs in North America are rare.

Furthermore, in examination of nearly two-dozen grassland-based green roofs Sutton et al (2012) found many planted to native grasses and admixtures of native grass and forbs with Sedum. They also reported on and located extensive and semi-intensive green roofs in central North America where native grasses and forbs alone have adequately met the programmatic objectives and suggested such plants could grow well on green roofs in New England and the Mid- Atlantic regions. Yet to date, low-diversity plantings of stonecrop (Sedum spp.) dominate most green roofs (Koehler 2003, Oberndorfer et al 2007). Cook-Patton and Bauerle (2012) suggest that plant diversity on green roofs needs to be more broadly interpreted beyond simple species richness, (e.g., three or four species of Sedum) but extended to functional group diversity, functional trait diversity, phylogenetic diversity and structural complexity. Lundholm et al (2010) have indicated that varying plant canopy heights and types improved moisture capture. It is apparent that extrapolating from Lundholm et al (2010) native grasses of different growth habits alone and in combination with forbs could more closely meet this ability to capture water than mono-generic Sedum spp. mats

Why is there lack of research interest on the use of native plants - particularly grasses - and their installation by seeding? Perhaps widely cited research (91 citations) by Monterusso et al (2005) reporting on drought losses of a few native plants tested alongside stonecrop species on a green roof has apparently obviated detailed examination of native grass use on green roofs. However, Dvorak and Volder (2010) question applicability of Monterusso et al's results for native grasses because of the shallow media depth in which they were grown. Sutton et al (2012) question Monterusso et al's research design as lacking sufficient establishment time for native grass roots to withstand drought in the middle of the second year growing season.

The observations and research on the seeding and maintenance of several native grasses described herein began in 2007 with a small green roof planted to plugs of native grasses and wildflowers at the Pioneers Park Nature Center (PPNC). There, like those projects listed above, 6 of 20 species planted on the roof seeded freely and the second year readily filled gaps between plugs. Reported below are a series of three on-the-roof trials conducted over three years, with observations, experiments, and techniques that evaluate planting season, method, depth, plant spacing, resulting plant vigor, time to and visual density of cover, and costs when using native grasses on green roofs. Finally, based on these experiences we also suggest maintenance protocols.

\section{Three Trials and Venues}

\section{BACKGROUND}

From 2010 to 2013, three cooperating organizations (Arbor Day Foundation = ADF, Sandhills Publishing = SHP, and Larson Building-Parkhaus Apartments = LB-P) allowed use of their green roofs for studying feasibility of native grass and forb use. These roof venues were located in Lincoln, Nebraska (Table 1.) which falls in the Loess and Glacial Drift Hills Eco-region where the hot, continental climate can experience rapid and broad swings of temperature, humidity, precipitation and wind. Periods without precipitation can and do occur regularly in any month. The green roofs had 
substrate depths ranging from ultra-extensive (2-in) to extensive to semi-intensive (25\% above or below 6-in). Several native grasses were examined from a suite including, but not limited to: Sideoats grama (Bouteloua curtipendula), Buffalograsss (B. dactyloides), Blue grama (B. gracilis), Hairy grama (B. hirsuta), Junegrass (Koeleria cristata), Plains muhly (Muhlenbergia cuspidata), Little bluestem (Schizachyrium scoparium), and Sand dropseed (Sporobolus cryptandrus). Not all grass species listed were tested on all green roof sites. While the listed grasses are associated with various prairie communities in the central United States, local populations of each can be found beyond that region (Jefferson et al 2002; also see Hitchcock 1950 for species maps.) For example, little bluestem and sand dropseed grow in nearly all states east of the Rockies, and local sources of native grass seed are often available due to decades of range and pasture improvement research and prairie restoration efforts (Launchbaugh and Owensby 1970, Bailey and Martin 2007, Schramm 1990).

Table 1. Basic characteristics of native plant research trial venues, in Lincoln, Nebraska.

\begin{tabular}{|c|c|c|c|c|}
\hline $\begin{array}{l}\text { Venue and } \\
\text { Year }\end{array}$ & $\begin{array}{l}\text { Pioneers Park } \\
\text { Nature Center } \\
\text { (PPNC) } 2007\end{array}$ & $\begin{array}{l}\text { Trial One Arbor } \\
\text { Day Foundation } \\
\text { (ADF) } 2010\end{array}$ & $\begin{array}{l}\text { Trial Two } \\
\text { Sandhills } \\
\text { Publishing } \\
\text { (SHP) } 2011\end{array}$ & $\begin{array}{l}\text { Trial Three Larson } \\
\text { Bldg-Parkhaus } \\
\text { (LB-P) } 2012\end{array}$ \\
\hline $\begin{array}{l}\text { Substrate } \\
\text { depth }\end{array}$ & 3-1/2 (9 cm)in & 2 in $(5.1 \mathrm{~cm})$ & 6 in $(15.3 \mathrm{~cm})$ & $\begin{array}{c}4-8 \text { in }(10.1-20.2 \\
\mathrm{cm})\end{array}$ \\
\hline Substrate type & $\begin{array}{l}\text { rooflite }^{\mathrm{TM}} \mathrm{EC}- \\
\text { Extensive }^{-}\end{array}$ & $\begin{array}{l}\text { Carlisle }^{\mathrm{TM}} \text { : West } \\
\text { Coast Ultra-light } \\
\text { Extensive }\end{array}$ & $\begin{array}{l}\text { Custom mix } \\
\text { Lyman-Richie, } \\
\text { Waterloo, NE }\end{array}$ & $\begin{array}{l}\text { Midwest Trading } \\
\text { Extensive }\end{array}$ \\
\hline Area & $800-\mathrm{ft}^{2}\left(74 \mathrm{~m}^{2}\right)$ & $7,000-\mathrm{ft}^{2}\left(650 \mathrm{~m}^{2}\right)$ & $1,150-\mathrm{ft}^{2}\left(107 \mathrm{~m}^{2}\right)$ & $6,000-\mathrm{ft}^{2}\left(558 \mathrm{~m}^{2}\right)$ \\
\hline Slope & $1 \%$ & $1 \%$ & $1 \%$ & $2 \%$ \\
\hline System & $\begin{array}{l}\text { Amer. Hydrotech } \\
\text { Gardenroof }{ }^{\mathrm{TM}} ; \\
\text { root barrier over } \\
\text { TPO }\end{array}$ & $\begin{array}{l}\text { Carlisle }{ }^{\mathrm{TM}} \text { with } \\
\text { moisture retention } \\
\text { mat \& root barrier } \\
\text { over EPDM }\end{array}$ & $\begin{array}{l}\text { Carlisle Mira- } \\
\text { drain } 4^{\mathrm{TM}} \text { over } \\
\text { EPDM }\end{array}$ & $\begin{array}{c}\text { N-VIRE Mat } 075 N- \\
1 \text { \& root barrier over } \\
\text { EPDM }\end{array}$ \\
\hline Accessibility & Not Accessible & Not Accessible & Accessible & Privately Accessible \\
\hline $\begin{array}{l}\text { Bldg. } \\
\text { Height/Type }\end{array}$ & $\begin{array}{l}\text { 1-story over } \\
\text { commons/entry }\end{array}$ & $\begin{array}{l}\text { 2-story above } \\
\text { office/commercial }\end{array}$ & $\begin{array}{c}\text { 1-story over } \\
\text { parking garage }\end{array}$ & $\begin{array}{c}\text { 8-story over parking } \\
\text { garage }\end{array}$ \\
\hline Irrigation & Yes & Yes & Yes & Yes \\
\hline Method & Hand & Hand & Hand & Hand \\
\hline Frequency & Weekly & Weekly as needed & Weekly & Weekly \\
\hline
\end{tabular}




\section{General Materials and Methods for All Venues}

Each green roof venue had its own unique array of design and physical conditions, circumstances related to the cooperator's goals, construction specifications and installation dates that, in turn, constrained the timing, relationship, and extent of experimental designs and statistical comparisons. Plots at all three trial venues were randomly assigned treatments and had a 6-in wide unplanted buffer strip separating all edges and plots. Since seeding leaves the substrate exposed to wind scouring, all seeded areas were covered with ENCAPTM erosion control polymer at rate of 5-oz/ $\mathrm{ft}^{2}$.

For all venues the estimated visual cover was examined in the fall at growing season's end using a half square meter quadrat frame. For each plot at all venues a $5.28-\mathrm{ft}^{2}$ quadrat frame measured the coverage of plants then was converted to percent visual estimates of cover and rounded to the nearest $5 \%$. At ADF and SHP small plots allowed the entire plot to be estimated. (See the next section on specific venue sections for roof and plot setup.)

On the larger LB-P green roof, twenty-four places totaling 129.2- $\mathrm{ft}^{2}$ (about $4.3 \%$ of the entire green roof) were sampled for both Sedum and native grasses plantings after being randomly chosen so a wide sample of the area was included. The method at LB-P started from 6 distributed points each for the Sedum spp. and the native grasses; the sampler moved into the planted area three paces, stopping and dropping the quadrat frame behind the back at 4 places approximately facing $0^{\circ}, 90^{\circ}, 180^{\circ}$, and $270^{\circ}$ azimuths. As a measure of plant vigor, seed yield was compared for seeded and plugged hairy grama at both $\mathrm{ADF}$ and SHP.

\section{MATERIALS AND METHODS FOR SPECIFIC GREEN ROOF VENUES}

\section{ADF and SHP Trials}

In 2010 a 20 -ft by $20-\mathrm{ft}$ portion of the 7,000-ft $\mathrm{ADF}$ green roof was subdivided into 16, 4-ft by 4-ft plots and randomly assigned native seeding and planting treatments (Table 2). Observations focused on plant vigor (size and seed yield) and visual coverage as affected by season seeding and live plant spacing. One plot was left unplanted and three plots of 72 plugs (72 plugs per tray) were planted to general survival trials for various other species of sedges and forbs to see how well they performed; those plots are not reported here. In September of 2010 and May of 2011, three random plots each were seeded with a mixture of grass and forb species at a depth of 1-in in rows 4-in apart. Also, grass, sedge, and forb species admixtures were planted randomly as 72's plugs at 6-in on center in three plots and at 8-in on center in an additional three plots. No sedum was planted or examined. Grass and forb seed mixes contained species with small and often hirsute seeds; static electricity made handling and planting difficult and time-consuming especially in windy conditions. Consequently .75-oz. of fine sand was mixed with the seed and transported in self-sealing plastic sandwich bags. 


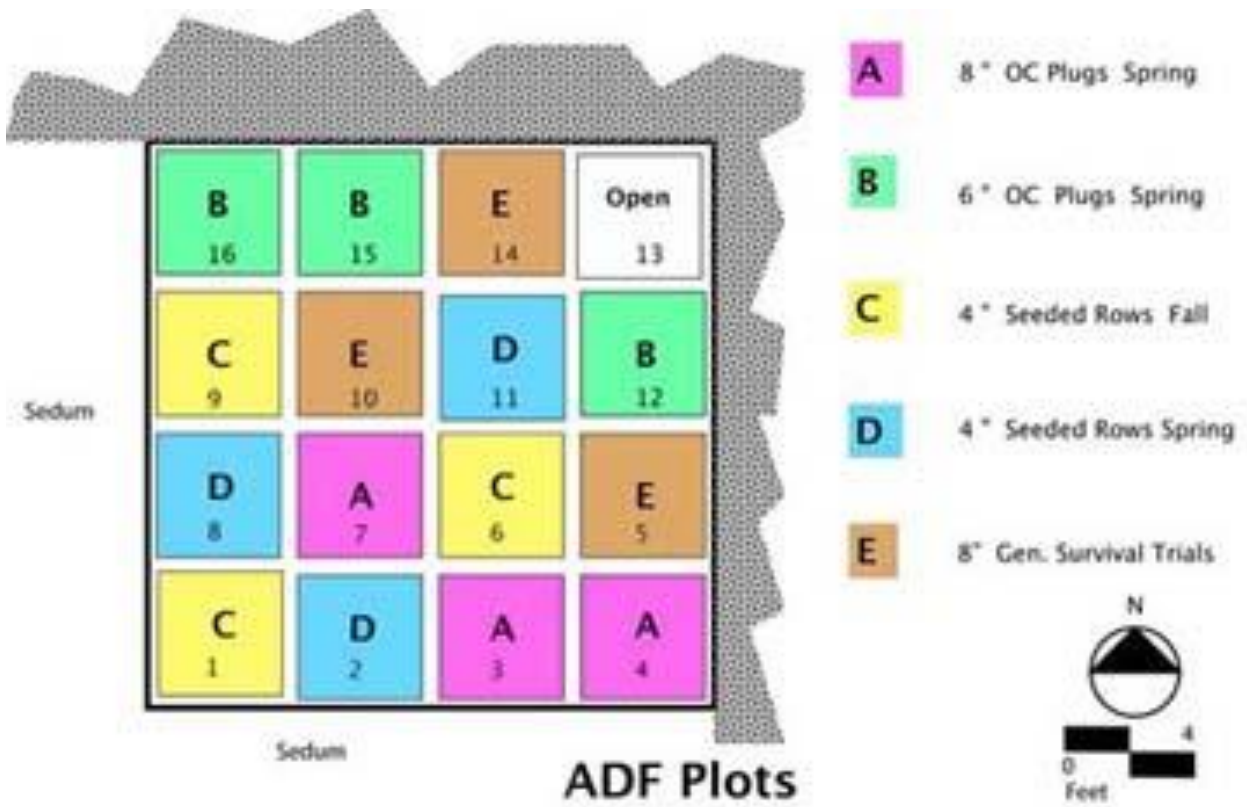

Figure 1. Plot layout and randomization for the $20-\mathrm{ft}$ by $20-\mathrm{ft}$ ADF native plant green area set in context with Sedum. Three plots (E) were general survival trials and not compared for cover or vigor.

Table 2. Species assigned to12, 4-ft X 4-ft treatment plots at ADF.

Species

\section{Seeding 4-in Rows}

C

\begin{tabular}{llcccc} 
Common Name & Botanical Name & Fall & Spring & 6-in & 8-in \\
\hline Dwarf leadplant & Amorpha nana & X & X & & \\
Fringed sage & Artemisia frigida & X & X & X & X \\
Fendler aster & Aster longifolius & X & X & X & X \\
Blue grama & Bouteloua gracilis & X & X & X & X \\
Hairy grama & Bouteloua hirsuta & X & X & X & X \\
Sun sedge & Carex inops heliophila & X & X & X & X \\
Brevior sedge & Carex brevior & & & X & X \\
Purple prairieclover & Dalea purpurea & X & X & X & X \\
Prairie junegrass & Koeleria pyramidata & X & X & & \\
Plains muhly & Muhlenbergia cuspidata & & $\mathrm{X}$ & &
\end{tabular}

\section{Spring Plugging O. C.*}

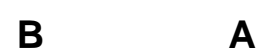




\section{Schizachyrium}

Little bluestem

Sand dropseed scoparium

Sporobolus cryptandrus $x$

$x$

$\mathrm{X}$ $x$

X

$x$

$x$

* O. C. means on center spacing.

In late May of 2011, a $20-\mathrm{ft}$ by $20-\mathrm{ft}$ portion of the $1150-\mathrm{ft}^{2}$ SHP green roof (Figure 2) was subdivided into 16, 4-ft by 4-ft plots (Figure 3). The SHP venue had a substrate 4-in deeper than ADF 6-in versus 2-in; row spacing at SHP was 6-in, 2-in wider than ADF. Wider, row spacing and deeper substrate at SHP might allow more volume for developing roots compared to plots at ADF. Three randomly assigned plots each were hand-seeded to pure renditions of one of five species: hairy grama, blue grama, sideoats grama, plains muhly, or little bluestem. The sixteenth plot was located at the downspout and not used. Other than row width, seeds were processed and planted in a similar fashion to ADF.

Examination of planting season effects were possible only at ADF because that green roof was completed and ready for planting in September 2010 and in May of 2011. Trial 3 located at the Sandhills Publishing (SHP) was not available for planting until May of 2011 so it was evaluated only for row spacing and competition in a deeper substrate, not season of planting.

As a measure of plant vigor, seed yield was compared for seeded and plugged hairy grama at both $\mathrm{ADF}$ and SHP. Because more than one inflorescence (group of flowers) grew per culm, seed yield from each was averaged on a per inflorescence basis. Sixteen random seed culms with inflorescences were selected from each of ADF and SHP plots and from among 11 plants of plugged hairy grama in an adjacent green roof bed at SHP planted in May 2011as a separate species trial. 


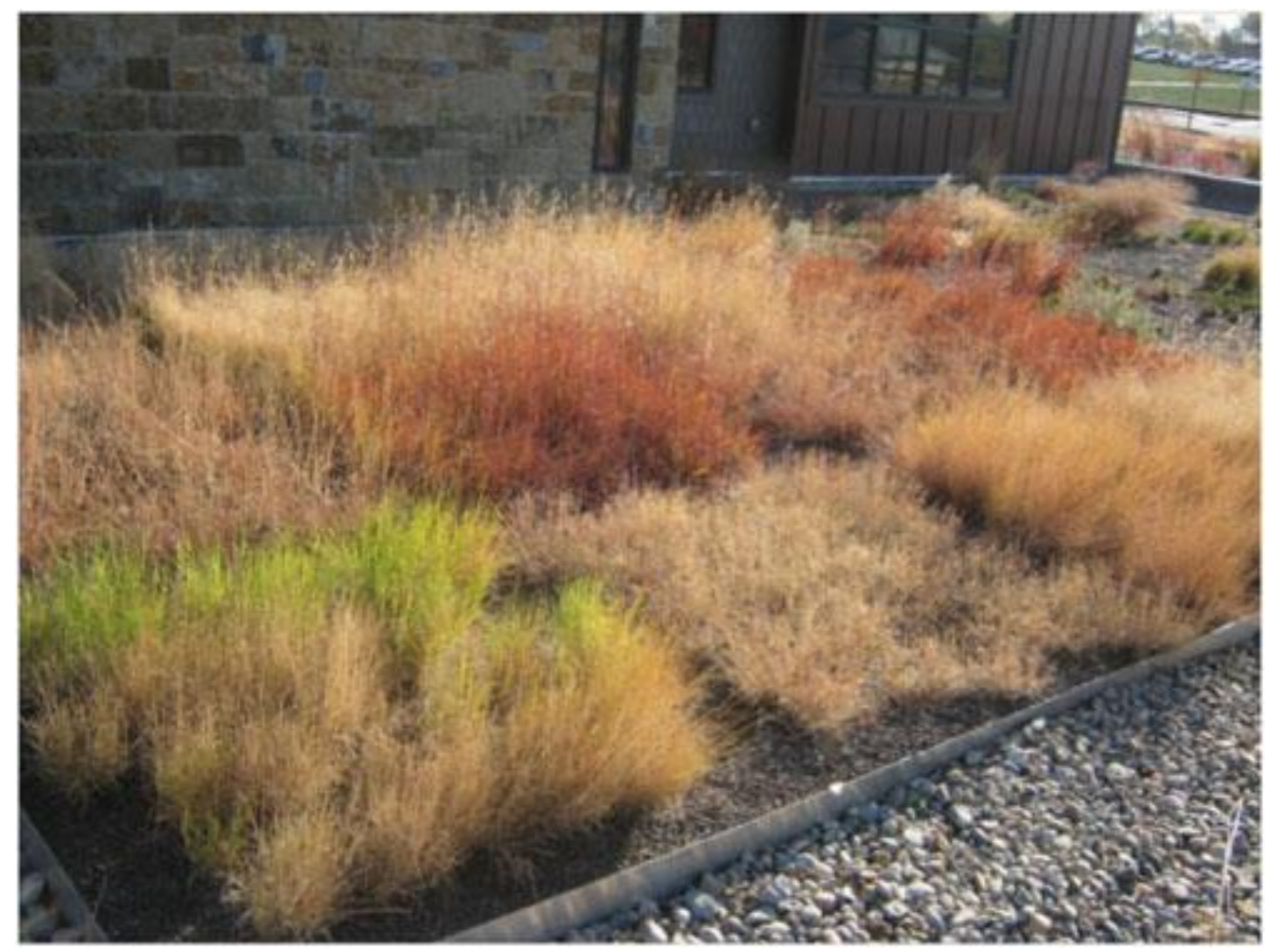

Figure 2. Sandhills Publishing (SHP), Trial Venue Two shown during late-season of first year (2011). 


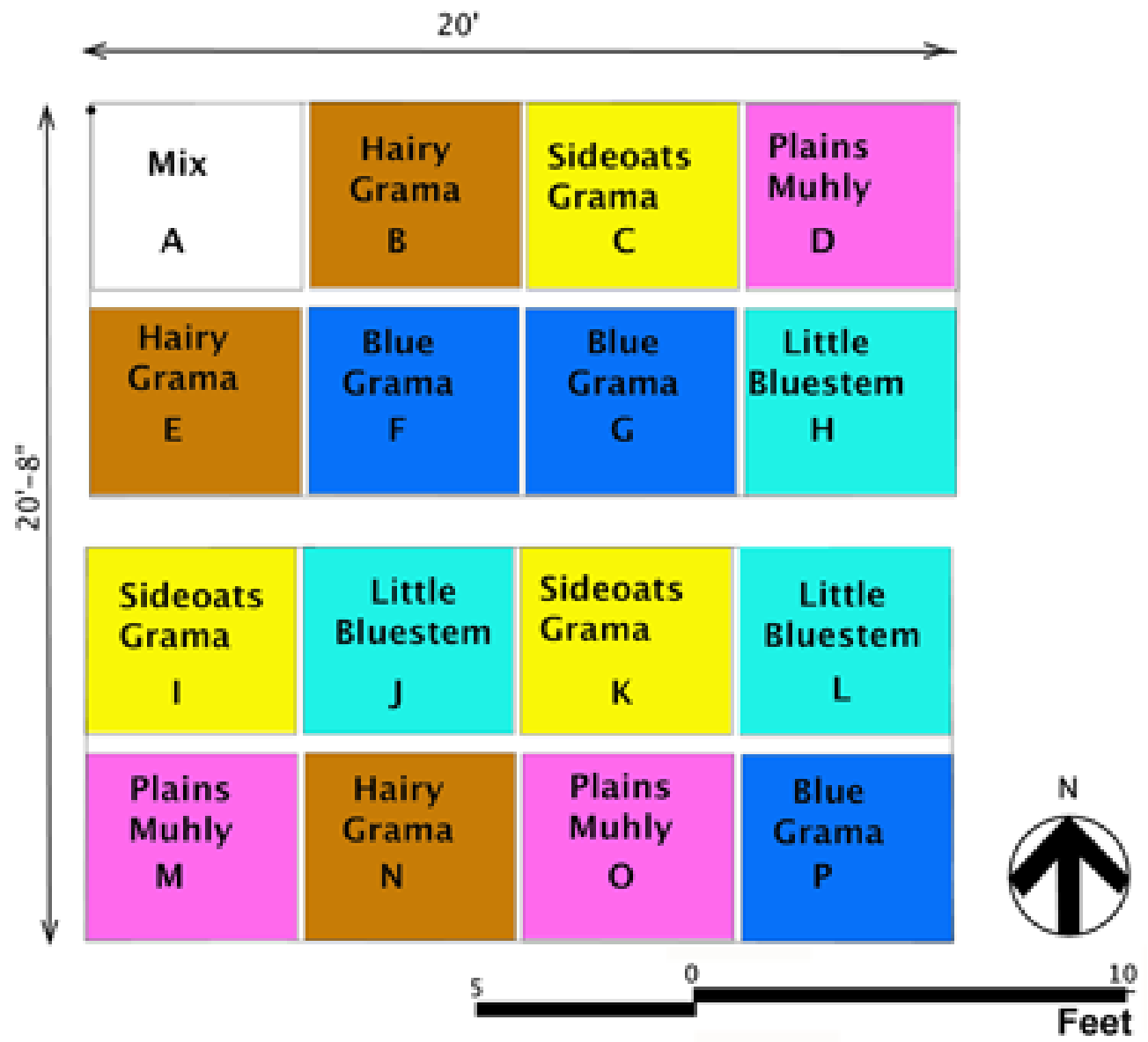

Figure 3. Plot layout and randomization for the 20-ft by $20-\mathrm{ft}$ SHP native plant seeding study.

\section{LB-P Trial}

In June of 2012 several plots were embedded in the 6,000- $\mathrm{ft}^{2}$ Parkhaus-Larson Building (P-LB) green roof (Figure 4). This trial was required to fit within a pre-designed layout (Figure 5) and had two distinct objectives. First, based on previous work at SHP and species' germination test estimates of the probable seedlings per $1-\mathrm{ft}$ of planted furrow. Three LB-P plots were precision planted to randomized single-species rows of pelletized seed to test the seeding rate required for $80 \%$ coverage. 


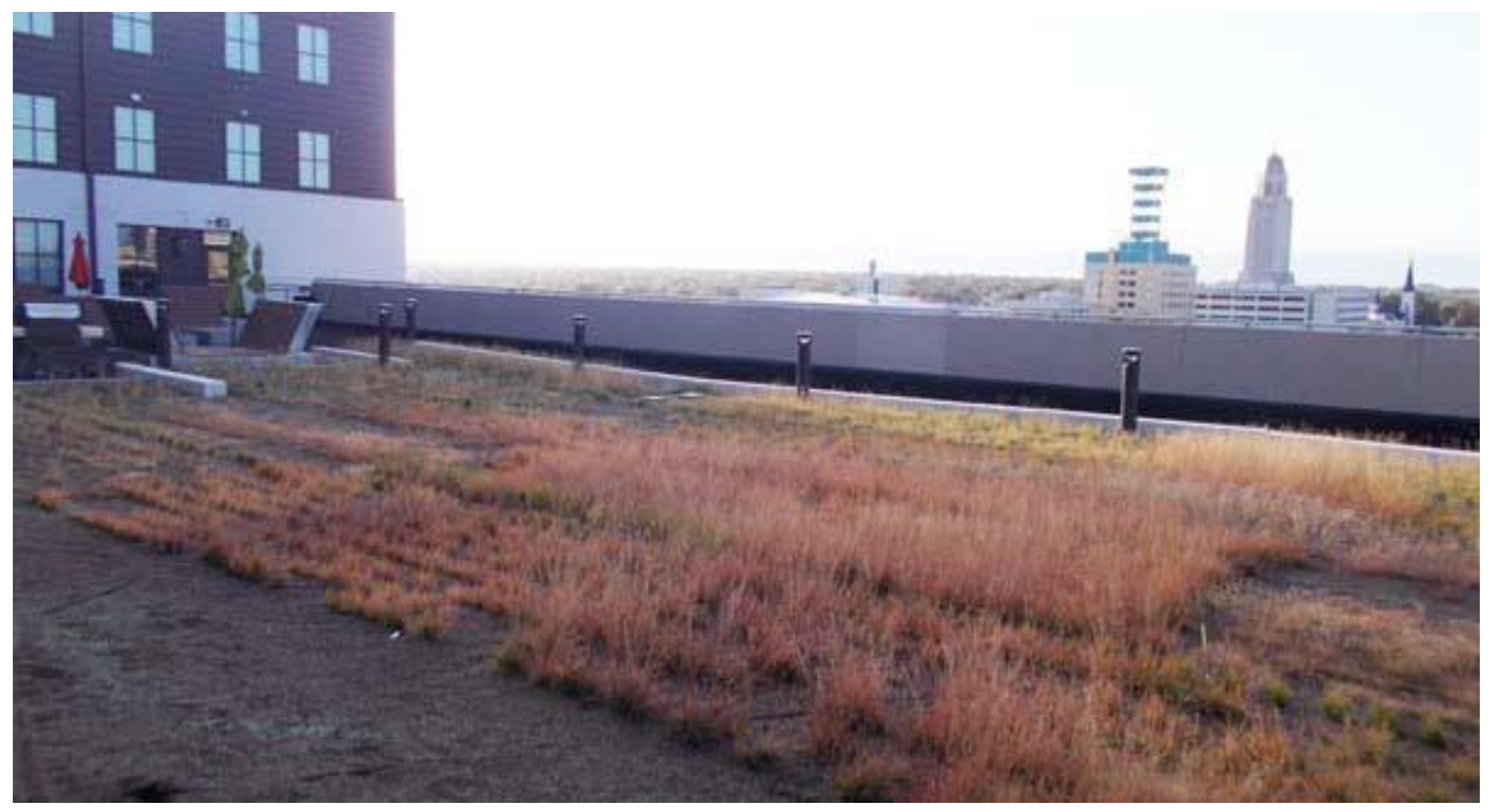

Figure 4. Larson Building-Parkhaus (LB-P) Trial Venue Three during the late season of the first year (2012).

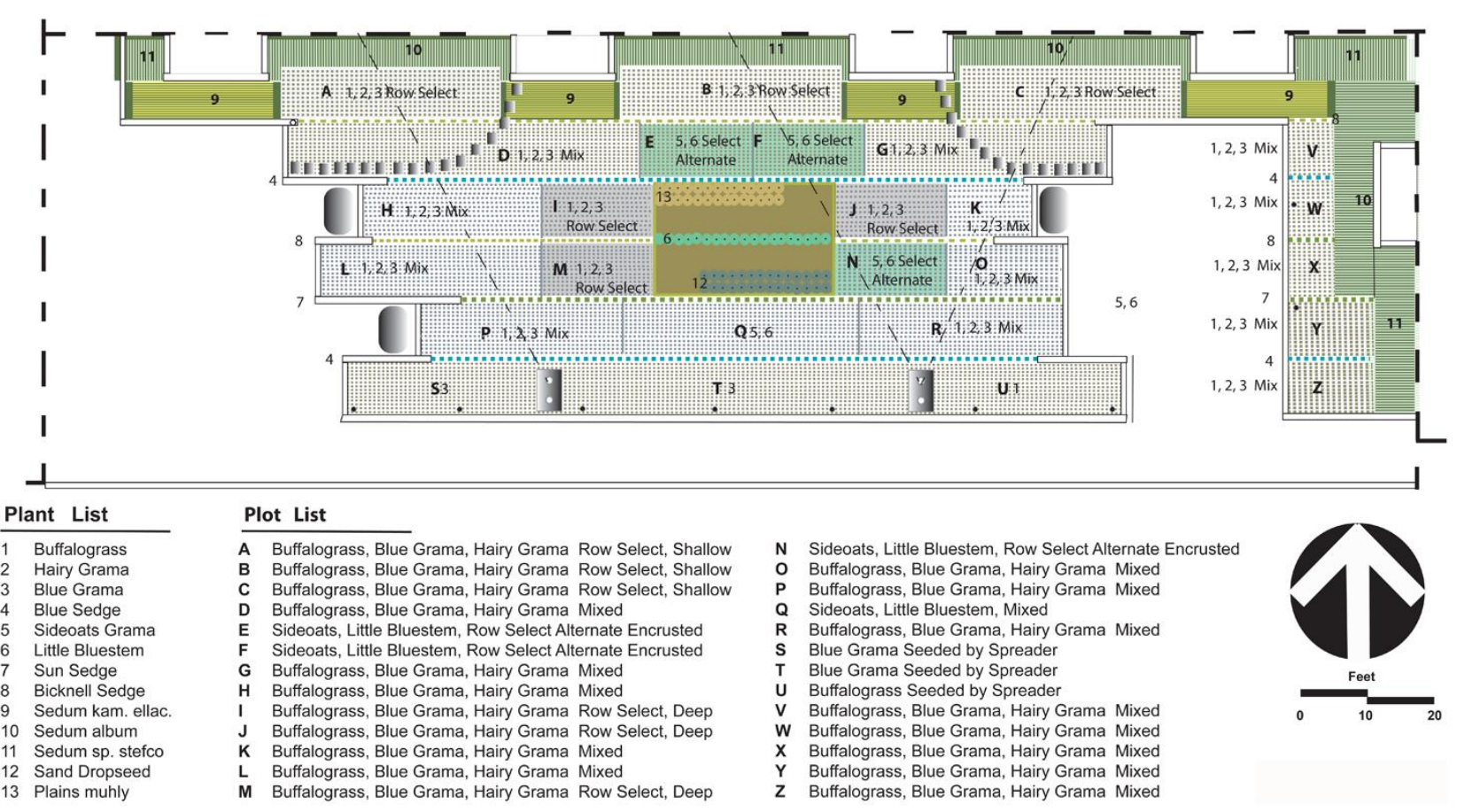

Figure 5. Plots were set within and conformed to the designed layout for LB-P. 
Three key elements were needed to employ precision seeding of native grasses. First, pre-planting treatment of seed by encrusting or pelletizing (Kamterter Products, Inc. Waverly, Nebraska) removed problems of angular seed shape, hairs and static electricity buildup while adding weight to help seed dispersal that caused difficulties hand-seeding at ADF and SHP. Buffalograss seed was mechanically deburred to allow for ease in pelletizing individual seeds. None of the seed was primed or chemically treated before pelletizing. The treated seed was planted at a depth of 1-in using a precision garden seeder. Second, for each species and seed treatment, Kamterter, Inc. performed 14-day quality control germination tests. Treatments included controls (plain, non-pelleted and non-primed), and treated (encrusted or pelleted) seed samples germinated in a constant $20^{\circ} \mathrm{C}$ or an alternating $68^{\circ}-86^{\circ} \mathrm{F}(16$ hours at $68^{\circ} \mathrm{F}$ ) and 8 hours at $86^{\circ} \mathrm{F}$ ) temperature regime (Table 3). Finally, based on seeding at ADF and SHP and the known germination of the pelletized seed an estimate of the number of plants per length of row was prepared to guide precision planting at LB-P.

Table 3. Fourteen-day quality control germination trials prepared by Kamterter, Inc. for pelletized, encrusted and raw seeds (Data courtesy of Kamterter, Inc.)

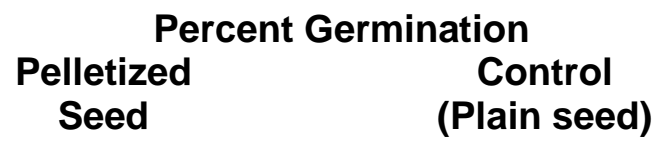

\begin{tabular}{|c|c|c|c|c|}
\hline Cultivar and Species & $\begin{array}{c}68^{\circ} \mathrm{F} \\
\left(20^{\circ} \mathrm{C}\right)\end{array}$ & $\begin{array}{c}68-86^{\circ} \mathrm{F} \\
\left(20-30^{\circ} \mathrm{C}\right)\end{array}$ & $\begin{array}{c}68^{\circ} \mathrm{F} \\
\left(20^{\circ} \mathrm{C}\right)\end{array}$ & $\begin{array}{c}68-86^{\circ} \mathrm{F} \\
\left(20-30^{\circ} \mathrm{C}\right)\end{array}$ \\
\hline ‘Bad River’ blue grama & $86 \%$ & $92 \%$ & $90 \%$ & $94 \%$ \\
\hline Hairy grama & $22 \%$ & $22 \%$ & $24 \%$ & $10 \%$ \\
\hline 'Connard' blue grama & $44 \%$ & $40 \%$ & $50 \%$ & $52 \%$ \\
\hline 'Cody' buffalograss* & $68 \%$ & $64 \%$ & $66 \%$ & $56 \%$ \\
\hline
\end{tabular}

*Note: Greater 6-day germination (66\%-84\%) of deburred buffalograss occurred compared to other species. Treatments included controls (plain, non-pelleted and non-primed), and treated (encrusted or pelleted) seed samples germinated in a constant $20^{\circ} \mathrm{C}$ or an alternating temperature regime with 16 hours at $68^{\circ} \mathrm{F}\left(20^{\circ} \mathrm{C}\right)$ and 8 hours at $86^{\circ} \mathrm{F}\left(30^{\circ} \mathrm{C}\right)$.

Finally, At LB-P we also recorded the installation times of Sedum spp. plugs and grass seeding on a per square foot basis. Times to plug eleven Sedum spp. plots totaling $1413 \mathrm{ft}^{2}$ were compared to eleven precision seeding plots totaling $1779 \mathrm{ft}^{2}$. Seeding was done using a hand-seeder (1001-B Precision Garden Seeder, Bristol, Indiana). Hairy grama seedings used a custom plate with $4.4 \mathrm{~mm}$ orifices at $2.53 \mathrm{~cm}$ spacing. Blue grama and buffalograss seedings used a \#18108 plate with a $3.8 \mathrm{~mm}$ orifice and $11.4 \mathrm{~cm}$ spacing. On the remaining $2808-\mathrm{ft}^{2}$ non-plot area of the green roof, workers were allowed to plant seed while familiarizing themselves with changing plates, filling the seed hopper, and managing row spacing and straightness prior to timing the seeded plots. 


\section{Results}

\section{PLANT COVERAGE}

When comparing the visual cover of fall- or spring seeded plots at ADF to those planted to plugs we found the seeded plots lagged about two months behind the plugs in reaching $80 \%$ cover by the end of the first growing season. However, four of the six seeded and the same number of plugged plots met or exceed $80 \%$ coverage by the end of the second (2012) growing-season (Figure 6). There appeared to be no difference between fall and spring seeding. At SHP several species' first season (blue grama, hairy grama, and little bluestem) met or exceeded $80 \%$ coverage (Figure 7). Establishment results from the three, pelleted, precision-seeded plots at LB-P are shown in Figure 8. There, coverage from 'Cody' Buffalograss averaged 3 or 4 plants per $3.3-\mathrm{ft}$ resulting in $70 \%$ coverage; hairy grama averaged 3 or 4 plants per $3.3-\mathrm{ft}$ with $40 \%$ coverage; blue grama averaged 1 to 2 plants about every 3.3 -ft with $20 \%$ coverage.

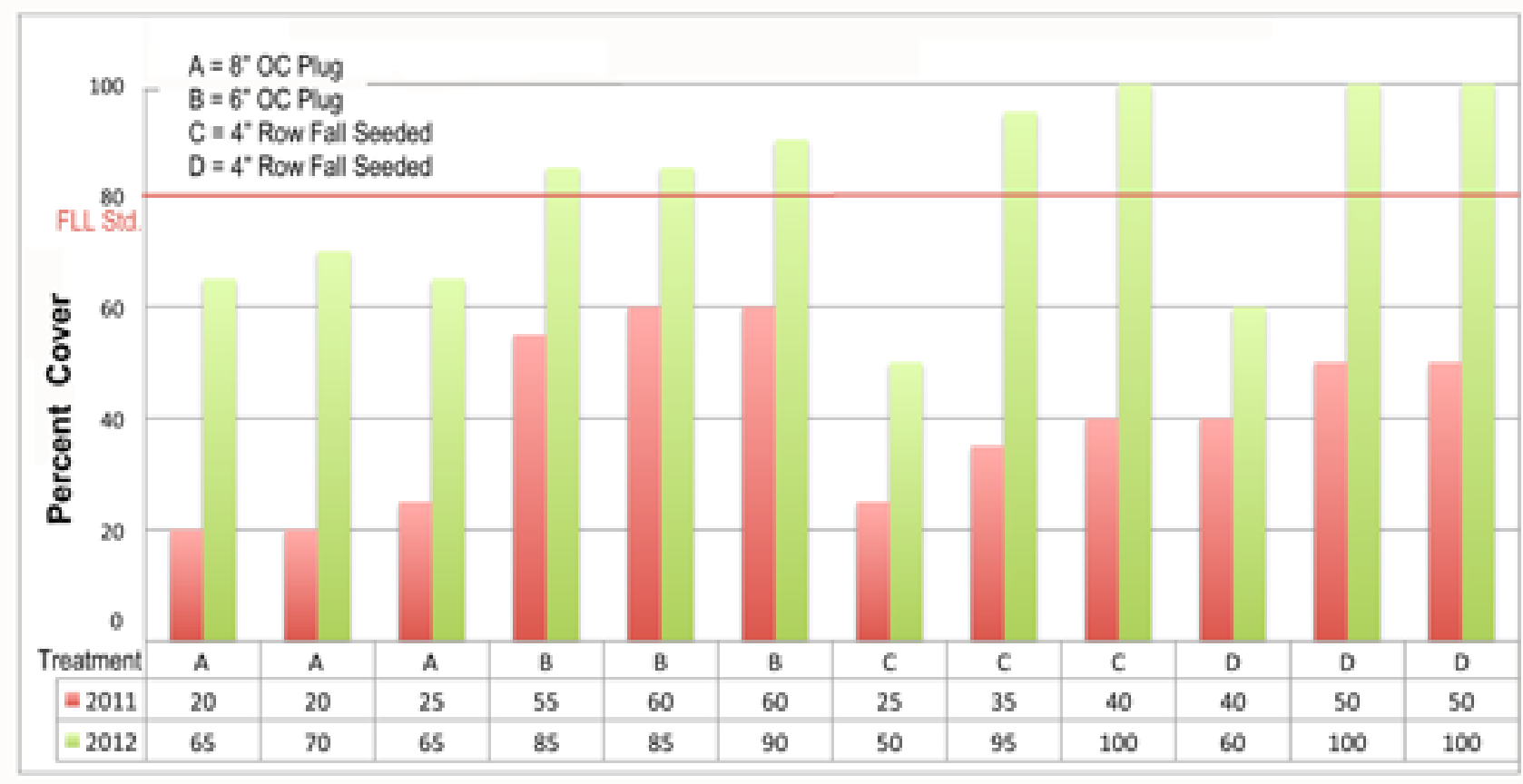

Figure 6. Visual coverage of native planting treatments (see Table 2) at ADF Trial Two 2011 and 2012. 


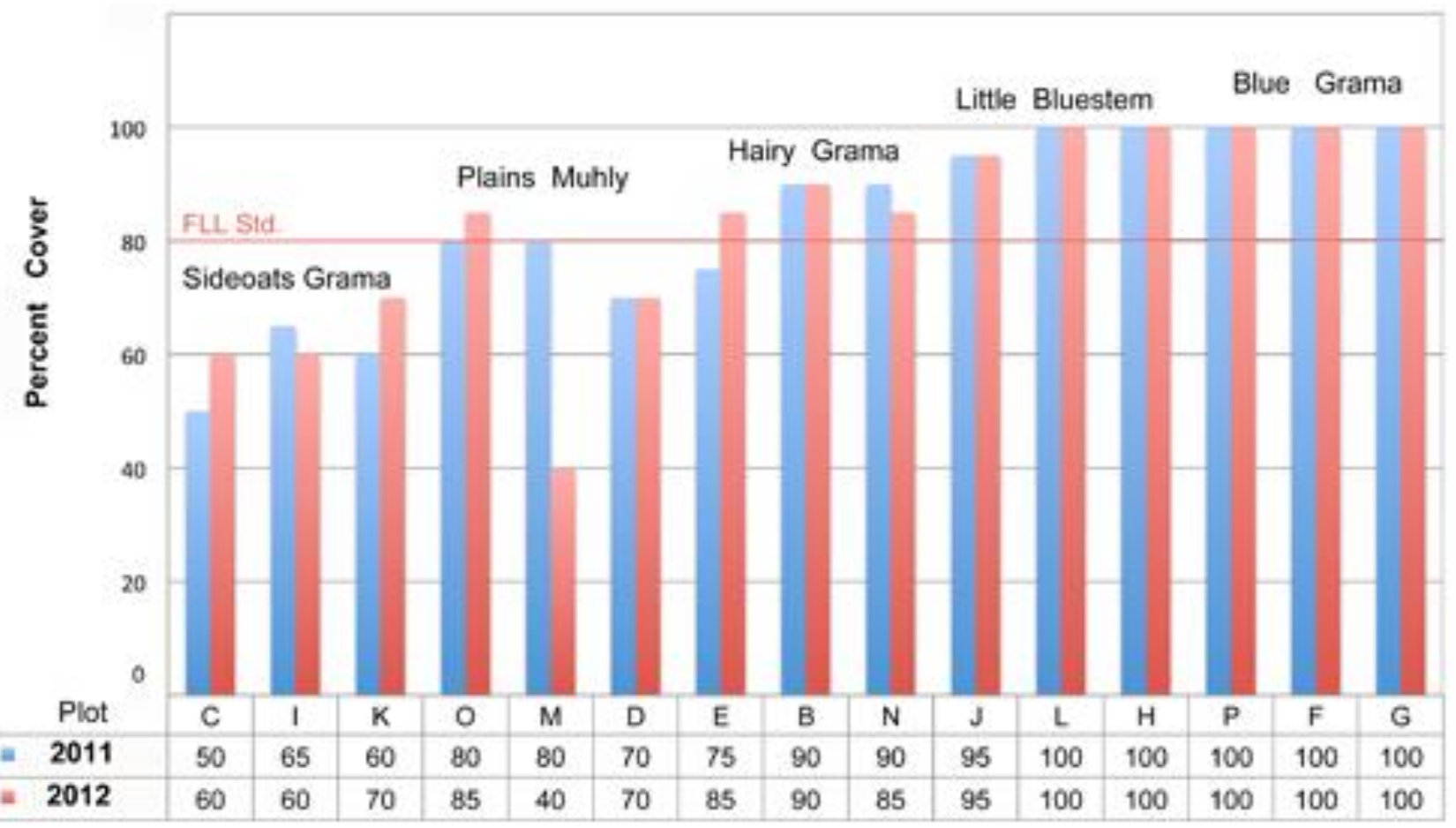

Figure 7. Visual coverage of species seeded plots at SHP Trial Three 2011 and 2012.

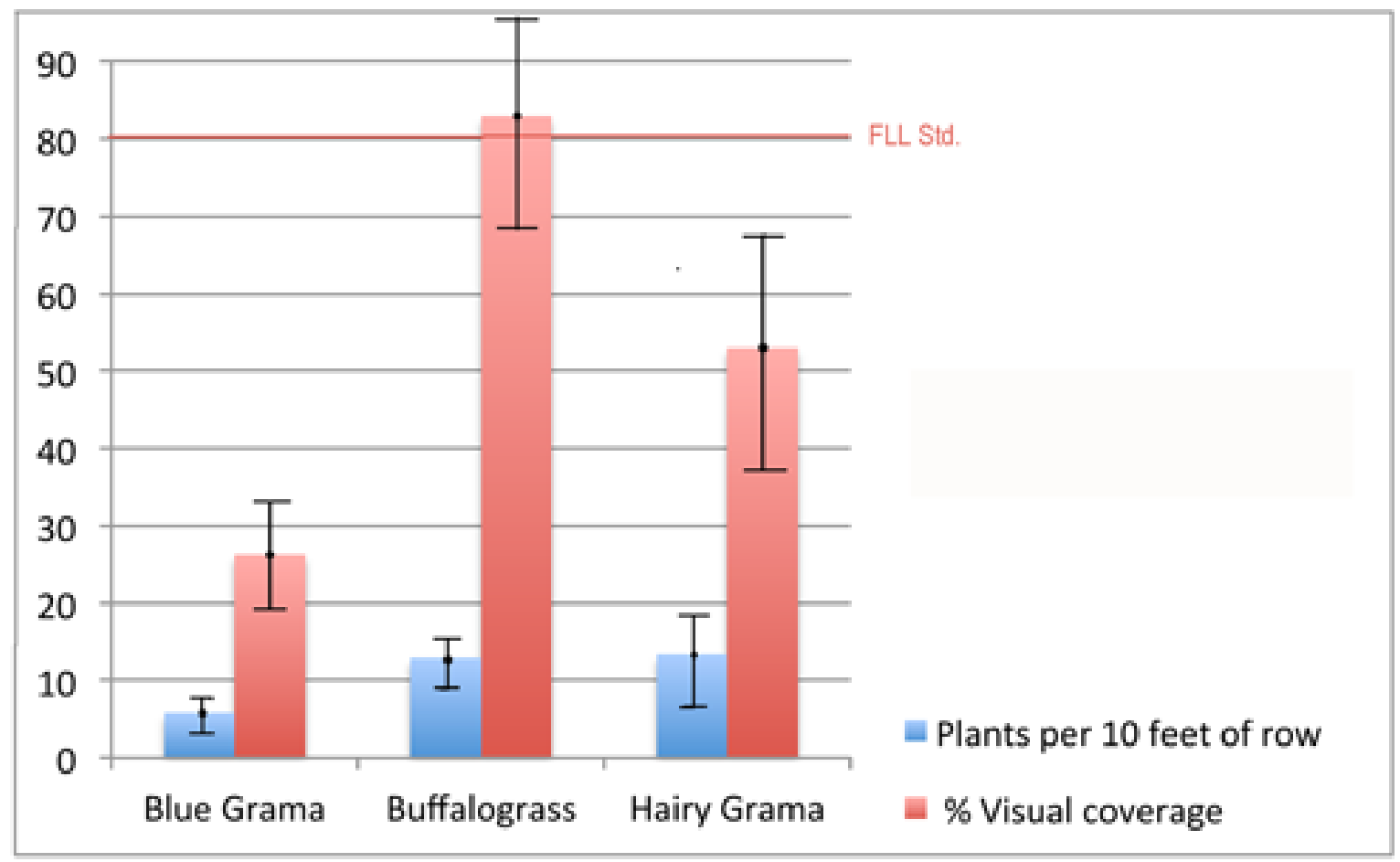

Figure 8. Plants per row and visual coverage of precision-seeded native grasses at LB-P shown with bars of one standard deviation. Data are mean \pm standard deviation $(n=6)$ 
Quadrat cover comparisons at LB-P between seed native grass rows spaced at 6-in and plugs of Sedum album and S. kamchaticum at 6-in on center spacing found average visual cover percentage before rounding for seeding to be $51 \%(\bar{x}=51 \%, \mathrm{n}=24, \mathrm{SD}=20.1)$ and plugging $23 \%(\bar{x}=23, \mathrm{n}$ $=24 . \mathrm{SD}=7.1$ ).

\section{PLANT VIGOR}

There must be wide enough spacing to encourage vigorous plants but the plant spacing must be close enough to limit gaps unprotected from scouring. This idea was tested on plantings at ADF, SHP and LB-P. Using seed yield of hairy grama as an indicator of vigor, seed yield for 4 -in rows with dense seeding was lowest, followed by 6-in densely seeded rows, then both 6-in and 8-in plugs producing the highest yield (Table 5).

Table 5. Seed yield from hairy grama infloresences under different treatments at ADF, SHP and LB-P Trials.

\begin{tabular}{llccl} 
Venue & Treatment & Inflores. $(\mathbf{n})$ & $\begin{array}{c}\text { Ave Seed Yield } \\
(\bar{x} / \text { Inflores. })\end{array}$ & SDev. \\
\hline ADF & 4-in Seeded Rows* & 35 & 14.36 & 1.59 \\
ADF & 6-in Plugs & 18 & 33.61 & 2.43 \\
ADF & 8-in Plugs & 18 & 33.00 & 1.37 \\
SHP & 6-in Seeded Rows & 18 & 22.78 & 2.21 \\
SHP & 8-in Plugs & 11 & 32.3 & 1.64 \\
LB-P & 6-in Seeded Rows & 16 & 32.1 & 2.34
\end{tabular}

*Both with similar, low variance so combined both fall and spring seeded plots.

\section{SEDUM VERSUS NATIVE GRASS COSTS: TIME AND MATERIALS}

Comparison of installation rates between seeding and traditional stonecrop plugging easily allows estimates of labor. Planting production rates for stonecrop averaged $480-\mathrm{ft}^{2}$ planted $/ \mathrm{hr}$ and precision seeding with pelletized native grass seed averaged $780-\mathrm{ft}^{2}$ planted $/ \mathrm{hr}$. Increased production rates for the seeding reduced labor costs by about $40 \%$. Additionally, the cost of seed per viable plant is much less than that of a 72-plug tray. Not accounted for in the comparison were the extra logistical costs of Sedum tray delivery and transport to a green roof, versus mobilizing the simple seeder and a bag of pelletized seed. While not attempted in the trial, a second precision garden seeder could be attached to the first, easily creating tandem, 6-in rows, effectively halving the native seeding time. 


\section{Discussion}

\section{COVERAGE}

Many forbs seeded in the ADF row mixtures did not establish successfully because of bird predation and miscommunication resulting in removal through mistaken weeding. Forbs that remained appeared at a competitive disadvantage to the more densely and quickly growing grass species. Another problem occurred when two of the three fall-planted and one 8-in on center plug plots were heavily impacted by a winterkill thought to be due to late winter desiccation caused by a poorly insulated kitchen below the roof.

Grasses in the fall seeding trial at ADF established successfully, but by the end of the first season little cover difference was observed between fall- and spring-seeded plots. For example, inflorescence heights of both fall and spring-seeded hairy grama plants were similar. It appeared that seeding represents a viable option for green roof planting, but densely seeding as if creating a lawn increases competition. At SHP, 6-in wide row and 6-in deep media reduced competition and five native grasses quickly established, dense cover. Precision planting at LB-P produced fewer seedlings than estimated. Due to differences in growth habit buffalograss (stoloniferous) averaged cover above the industry standard $80 \%$ and hairy grama (wide-spreading) covered around 50\%, both from plant densities of slightly over 1 plant per foot. Importantly buffalograss, hairy grama and blue grama were well anchored, vigorous, and produced copious seeds. For example, in counts from the first growing season on randomly selected hairy grama seed heads we found an average of over 32 seeds per inflorescence. This is similar to that of plugged 72's grown 6 and 8-in on center at ADF and at 8-in on center at SHP for two years (Table 5).

On the other seeded areas at LB-P the variability of the seeded cover percentage $(\bar{x}=51 \%, \mathrm{n}=24, \mathrm{SD}$ $=20.1)$ quadrat means compared to plugged sedum percentage $(\bar{x}=24 \%, \mathrm{n}=24, \mathrm{SD}=7)$ quadrat means, did not allow us to infer distinct differences between the two. Several factors may be at work. The greater coverage for seeding plots came from those with good stands of spreading, stoloniferous buffalograss. The bare areas appear to be associated with lower germination species and the precision seeder gaps possibly cause by operator error. Another factor may be that in the seeded area at LB-P media depth varied from to 4 to 9 -in. However based on observations at LB-P of seeding native grass, coverage is at the least equal to plugging sedum and in many areas better, just more variable.

\section{PLANT VIGOR}

At ADF we observed that plants established from plugs were larger with more extensive root systems and seemingly provided better wind and sun protection. They also engaged and held more substrate particles, and thus were more likely to resist drought and heat stress. Yet on the SHP green roof even with its substrate at three times the depth of ADF a similar pattern of intra-species competition also reduced the size of seedlings. So, while seeding into furrows at ADF and SHP eliminated poorly anchored plants, densely placing seeds brought unneeded plant stunting. Stunting and density may be encouraged for high input, traditional lawns and compensated for by mowing, fertilization, and irrigation but native grass green roofs focus upon low inputs, have a lower carrying capacity, and thus require lower seeding rates. 
Competition as indicated by spacing and rooting depth affected the hairy grama seed yield at ADF and SHP (Table 5). More rooting space resulted in more seed production. While the 6-in row spacing confounds with deeper substrate, data (Table 5) still strongly suggest that more root space leads to greater plant vigor and greater seed yield. More seed production means more seed available for infilling gaps on green roofs. Seeding native grasses on green roofs must balance spacing and coverage, but as noted in the previous section coverage is adequate to excellent in the first growing season.

\section{SEEDING VERSUS PLUGGING}

The real value of seeding native grasses on green roofs becomes apparent when examining costs. For example, at a $\$ 30 /$ hour labor basis when installing 72 's on a 1000 - $\mathrm{ft}^{2}$ green roof at 6-in on center, the Sedum roof incurs a material cost of about $\$ 5.00 / \mathrm{ft}^{2}$ and a labor cost of about $\$ 0.07 / \mathrm{ft}^{2}$ totaling $\$ 5.07 / \mathrm{ft}^{2}$. Precision seeding pelletized native grass seeding on a comparable sized roof area incurs a material cost of $\$ 0.75 / \mathrm{ft}^{2}$ and a labor cost of around $0.04 / \mathrm{ft}^{2}$ totaling $\$ 0.79 / \mathrm{ft}^{2}$ for a difference of $\$ 4.28 / \mathrm{ft}^{2}$ between seeding and plugging. Also, based on previous trials, establishment by seeding may quicken time to $80 \%$ cover and may be often achieved in the first growing season, while the stonecrop may take 2 to 3 growing seasons or longer for infill.

\section{Maintenance}

Complete on-going maintenance costs at the LB-P green roof will continue for an additional three years and are not reported here. While the differences in per area costs of labor and material for planting 72-plug trays versus precision seeding for pelletized native grass were substantial, maintenance of green roofs must also be considered. Stonecrop will require careful monitoring for weed infestations and annual testing and fertilization to keep it alive and floriferous (Koehler 2005, Emilsson 2008). Seeding with native grasses requires equal weeding diligence. Anecdotally, during the summer of 2013, the LB-P green roof was inspected and weeded every two weeks. This took about 30 minutes each time and has netted a total of 337 individuals of 8 weedy species. This was a spot and remove rate of $12,000 \mathrm{sf} / \mathrm{hr}$ or on a basis of $\$ 30$ labor amounted to one-quarter of a cent per square foot.

Fertilization, even with control-release fertilizers, can compromise the water quality benefits of a green roof (Emilsson 2008). Due to their unique physiology, the native, $\mathrm{C}_{4}$ native grasses studied require much less nitrogen than other herbaceous plants (Waramit 2010). Each year in central North America nitrogen deposits at a rate of 0.03 to $0.0015 \mathrm{oz} / \mathrm{msf}$ ( $8 \mathrm{~kg}$ to $4 \mathrm{~kg} /$ hectare) (NADP/NTN 2011). If we assume green roof substrate is similar to rangeland (Manske 2012) activated with the proper microorganisms then extrapolating amounts present on rangeland another 1 to $3 \mathrm{lbs} / \mathrm{msf}$ (4.8 to $\left.14.4 \mathrm{~g} / \mathrm{m}^{2}\right)$ for each inch $(2.54 \mathrm{~cm})$ of substrate depth can be supplied. Other inputs such as application of herbicides should be avoided, because of concerns about leaching from the welldrained substrate (Glass 2007, Burkhardt et al 2011). 


\section{IRRIGATION PROTOCOLS}

After a one-year establishment period, native grass seeding still required irrigation. In the extreme heat and drought of 2012, when less than 3/4-inches of precipitation fell in the critical growing season between July 1 and September 1, the grasses on the ultra-extensive ADF green roof were kept in excellent condition by irrigating with .5 -in of water per week $\left(\simeq 0.5 \mathrm{gal} / \mathrm{ft}^{2}\right)$. To establish plantings at PPNC, irrigation was applied by hand with protocols modified over six years in response to plant vigor as affected by changing plant coverage and erratic monthly temperatures and precipitation. A general guideline honed managing the PPNC green roof and used at SHP and LB-P during and after their establishment year, was that native grass roofs should receive at least 0.50 -in to 0.75 -in of water per 10 days either in rainfall or irrigation. At PPNC the establishment phase ran from 2007 to 2009. During 2007 we applied 0.25-in to 0.50-in of water every 7 days while ignoring rainfall. We modified water application by considering and counting precipitation greater than 0.25 -in during the week in 2008, and extended the time between watering to 10 days in 2009.

For a maintenance phase starting in 2010 we applied 0.25 in to 0.50 -in of water every 10 days and extended the growing season limits from April 1 to October 1. After a significant die-off due to heat and drought in August 2010 additional modifications were made, so that for every daytime with a maximum temperature above $99^{\circ} \mathrm{F}$, or nighttime with a minimum above $77^{\circ} \mathrm{F}$, we subtracted one day from the 10-day irrigation event cycle. For example, if during a cycle a daytime max was $100^{\circ} \mathrm{F}$ and a nighttime minimum $78^{\circ} \mathrm{F}$, the cycle length was reduced from 10 to 8 days.

We also incorporated an every other day visual inspection of the green roof planting during heat and drought periods and always checked the moistness of the substrate at several locations before irrigating. Season, depth of substrate and microclimatic factors such as wind and shading also affect water use. As plants grow they will also use more water. So currently, a weekly cycle of irrigation is being used to bring native grass green roofs through hot, dry periods. These are general recommendations; 'as needed during growing-season hot and or dry spells' means the plants and substrate should be monitored at least every other day. Moisture meters could also be used.

Another maintenance factor for native grass green roofs is removal of dry and dead biomass. To meet fire concerns or codes regarding litter buildup, grasses should be mowed or cut in the spring and clippings removed. Yes, this removes nitrogen form the system, but native grasses, unlike Sedum have over half their biomass below ground. Leaving the tops over winter allows them to still buffer winds and to disperse seeds for self-healing of openings.

\section{Summary}

1). Over six growing seasons 12 native graminoids (sideoats grama (Bouteloua curtipendula), buffalograsss (B. dactyloides), blue grama (B. gracilis), hairy grama (B. hirsuta), junegrass (Koeleria pyramidata), plains muhly, (Muhlenbergia cuspidata), little bluestem (Schizachyrium scoparium), sand dropseed (Sporobolus cryptandrus), purple three-awn (Aristida purpurea) sun sedge (Carex inops heterophila) Brevior sedge (Carex brevior) and Bicknell sedge (Carex bicknellii) were successfully established from seed or plugs on four separate green roofs; several species rapidly filled substrate gaps by self-seeding.

2). Seeding can occur in spring, late summer or early fall with no impact on coverage. 
3). Concerns about seedling density impacts on establishment success were addressed by use of precision applications of pelleted seed.

4). More widely spaced seedlings of hairy grama produced larger more vigorous plants leading to more seeds per inflorescence the first growing season assuming that more were available for selfseeding. This is most likely true for other grass species as well.

5). Seeding of native grasses was shown as a superior initial establishment method over plugging of Sedum spp. by producing quick, acceptable coverage at lower material and labor costs.

6). Maintenance requirements for native grasses versus Sedum spp. appear similar for weed control, reduced for fertilization, and more demanding for irrigation and biomass removal.

7). The trial green roofs planted to native grass plots with at least 6-in of substrate required irrigation on a weekly "as needed" basis during extreme dry or hot spells.

\section{Literature Cited}

Bailey, P., and C. Martin. 2007. "Regional availability of plants for prairie restoration." EMRRP Technical Notes Collection (ERDC TN-EMRRP-SI-31). Vicksburg, MS: U.S. Army Engineer Research and Development Center.

Beitz, M. 2011. Stand Persistence of Prestige Buffalograss (Bouteloua dactyloides) (Synonym Buchloe dactyloides) Under Simulated Green Roof Conditions During Summer in Oklahoma. MS Thesis Oklahoma State University, Stillwater, OK.

Bousselot, J.M., Klett, J.E., Koski, R.D., 2009. High elevation semi-arid taxa: evaluations on an extensive green roof. Paper presented at the Annual Greening Rooftops for Sustainable Communities Conference, Atlanta, GA.

Bousselot J., Klett J., Koski R. 2011. Moisture content of extensive green roof substrate and growth response of 15 temperate plant species during dry down. HortScience 46:518-522.

Burkhardt M, Zuleeg S, Vonbank R, Schmid P, Hean S, Lamani X, Bester K, Boller M. 2011. Leaching of additives from construction materials to urban storm water runoff. Water Sci Technol. 2011;63(9):1974-82.

Cook-Patton, S., and T. L. Bauerle. 2012. "Potential Benefits of Plant Diversity on Vegetated Roofs: A literature Review." Journal of Environmental Management 108 (2012) 85-92.

Dvorak. B. D. and A. Volder. 2010. "Green Roof Vegetation for North American Ecoregions: A Literature Review." Landscape and Urban Planning 96 (2010) 197-213.

Emilsson, T. 2008. "Vegetation Development on Extensive Vegetated Green Roofs: Influence of Substrate Composition, Establishment Method and Species Mix." Ecological Engineering. 33 (3-4): 265-277. http://dx.doi.org/10.1016/j.ecoleng.2008.05.005 
FLL (Forschungsgesellschaft Landschaftsentwicklung Landschaftsbau). 2008. Guidelines for the Planning and Maintenance of Green Roofing (English). Bonn, Germany. www.fll.de.

Glass, C. C. 2007. Green roof water quality and quantity monitoring. Unpublished report dated July, 26, 2007.

GRHC. 2006. Green Roof Design 101:Introductory Course Manual. $2^{\text {nd }}$ Ed. Cardinal Group, Inc. Toronto, Canada.

GRHC. 2013. Annual Green Roof Industry Survey 2012. Cardinal Group, Inc. Toronto, Canada. http://www.greenroofs.org/resources/SurveyReport2012FINAL.pdf last accessed July 30, 2013.

Hitchcock, A. S. and A. Case. 1950. Manual of the Grasses of the United States. USDA Misc. Publ. No. 200. US Government Printing Office, Washington, DC.

Jefferson, P. G., McCaughey, W. P., May, K., Woosaree, J., MacFarlane, L., and Wright, S. M. B. 2002. "Performance of American Native Grass Cultivars in the Canadian Prairie Provinces" Native Plants J. 3: 24-33.

Koehler M. 2003. "Plant Survival Research and Biodiversity: Lessons from Europe. Proceedings of Greening Rooftops for Sustainable Communities. May 29-30, 2008 Chicago, IL.

Koehler, M. 2005. "Long-Term Vegetation Research on Two Extensive Green Roofs in Berlin" Urban Habitats 4 (1):3-26. ISSN 1541-7115 http://www.urbanhabitats.org .

Narejo, D. 2010. "Green Roof Market Growth: Opportunities and Challenges." Geosynthetics. October. http://geosyntheticsmagazine.com/articles/1010_f4_green_roof.html .

Launchbaugh, J.L. and C.E. Owensby. 1970. "Seeding Rate and First-year Stand Relationships for Six Native Grasses." J. Range Management 23:414-417.

Lundholm, J.T. , J.S. MacIvor, J.Z. MacDougall, and M.A. Ranalli. 2010. "Plant Species and Functional Group Combination Affect Green Roof Ecosystem Functions." PLoS One 5 (2010: e9677. http://dx.doi.org/10.1731/journal.pone.0009677.

Manske, L.L. 2012. Biologically effective grazing management reduces the detrimental effect from drought conditions on grasslands. NDSU Dickinson Research Extension Center. Range Management Annual Report 2011. Dickinson, ND http://www.ag.ndsu.edu/DickinsonREC/ annual-reports-1/2011-annual-report/range11e.pdf (Last accessed August 26, 2013.)

Monterusso, M. A., B. D. Rowe, C. L. Rugh. 2005. "Establishment and Persistence of Sedum spp. and Native Taxa for Green Roof Applications." Hortscience, 40 (2005): 391-396.

NADP/NTN (National Atmospheric Deposition Program National Trends Network) 2011. Inorganic nitrogen wet deposition from nitrate and ammonium map. http://nadp.isws.illinois.edu/ maplib/pdf/2011/TotalN 11.pdf (Last accessed August 26, 2013). 
Oberndorfer, E, J. Lundholm, B. Bass, M. Connelly, R. Coffman, H. Doshi, N. Dunnett, S. Gaffin, M. Köhler, K. Lui, B. Rowe. 2007. Green Roofs as Urban Ecosystems: Ecological Structures, Functions, and Services." BioScience 57 (10) (2007): 823-833

Page, J. 1999. Site Work and Landscape Cost Data. RS Means/CDM Group Kingston, MA

Schramm, P. 1990. "Prairie Restoration: Twenty-five Year Perspective on Establishment and Management." Proceedings of the $12^{\text {th }}$ North American Prairie Conference, D. Smith and C. Jacobs, eds. August 5-9, Cedar Falls, IA. University of Northern Iowa, pp. 169-177.

Snodgrass, E and L. Snodgrass. 2006. Green Roof Plants. Timber Press, Portland, OR.

Snodgrass, E. and L. McIntyre. 2010. The Green Roof Manual. Timber Press, Portland, OR.

Sutton, R., J. Harrington, L. Skabelund, P. MacDonagh, R. Coffman, and G. Koch. 2012. "Prairiebased Green Roofs: Literature, Templates and Analogs." Journal of Green Building. Winter, 7 (1): 143-172. doi: 10.3992/jgb.7.1.143 .

Waramit, N. 2010. Native warm-season grasses: Species, nitrogen fertilization, and harvest date effects on biomass yield and composition. Ph D. Dissertation Iowa State University. 


\section{Acknowledgements}

We wish to thank the Lincoln, Nebraska green roof research venue cooperators at Pioneers Park Nature Center, Arbor Day Foundation, Sandhills Publishing, Inc., the City of Lincoln, Park and Go and Parkhaus Apartments for access to and use of their green roofs. Thanks to Kamterter, Inc. for pelletizing native grass seed used in one of the trials and use of their germination data. Thank you to Dr. Zac Reicher and Dr. Bill Gustafson for reviewing and commenting on earlier drafts and to two anonymous reviewers for their efforts.

\section{Funding}

A grant from the Fleming Horticulture Research Fund at the University of Nebraska-Lincoln (UNL) supported some of the trials. Undergraduate Creative Activity and Research (UCARE) at UNL supplied funding for several undergraduate research assistants from the UNL Program in Landscape Architecture. 